University of South Carolina

Scholar Commons

8-1997

\title{
The Dialectic in Contemporary Egyptian Social Thought: The Scripturalist and Modernist Discourses of Sayyid Qutb and Hasan Hanafi
}

Shahrough Akhavi

University of South Carolina - Columbia, akhavi@sc.edu

Follow this and additional works at: https://scholarcommons.sc.edu/poli_facpub

Part of the Political Science Commons

Publication Info

Published in International Journal of Middle East Studies, Volume 29, Issue 3, 1997, pages 377-401.

http://journals.cambridge.org/action/displayJournal?jid=MES

(C) 1997 by Cambridge University Press

This Article is brought to you by the Political Science, Department of at Scholar Commons. It has been accepted for inclusion in Faculty Publications by an authorized administrator of Scholar Commons. For more information, please contact digres@mailbox.sc.edu. 


\title{
Shahrough Akhavi
}

\author{
THE DIALECTIC IN CONTEMPORARY EGYPTIAN \\ SOCIAL THOUGHT: THE SCRIPTURALIST AND \\ MODERNIST DISCOURSES OF SAYYID QUTB \\ AND HASAN HANAFI
}

One of the most important arenas of the ferment in contemporary Arab social thought is Egypt. Egyptian writers have been contributing to a rapidly growing body of literature on state and society. Its themes include methodological issues, the nature of the ideal Islamic society; the elite-mass gap; the state's role in public life; the appropriate model for socioeconomic development; and the social bases of Islamist movements.

One dimension of contemporary Arab social thought has received less attention and merits further discussion. One is struck by the dialectic between the purposes of scripturalists and their utilization of modern concepts to promote traditionalist objectives; similarly, modernists, influenced by ideas of foreign provenance, feel compelled to try to reach their goals by reference to early kaläm. ${ }^{1}$ Seemingly, those debating "whither Arab society" take either of two very general perspectives: one that proposes solutions to the current problems of state and society by means of an ahistorical emphasis on the timeless truths of received religious knowledge; or a second that adopts a more critical attitude toward tradition, while nonetheless utilizing some of its concepts and working these into historically grounded analysis.

It is the capturing of this dialectic of scripturalist and modernist discourses that serves as the basic justification of this paper. Two contemporary writers seem to be prominent representatives, respectively, of scripturalist and modernist positions: Sayyid Qutb (1906-66) and Hasan Hanafi (b. 1935). Other Egyptian writers are important in this context, but I will examine the thought of these two in particular. Qutb has been the subject of several studies, including but not limited to those of Ibrahim M. Abu-Rabi ${ }^{\complement}$, Leonard Binder, Muhammad Hafiz Diyab, Yvonne Haddad, Gilles Kepel, Ahmad Moussali, ${ }^{C}$ Adnan Musallam, and W. Shepard. ${ }^{2}$ The choice of Hanafiless well known-seems apposite because he has explicitly presented his project as an antidote to the kind of scripturalism represented by Qutb, while harboring the same aspiration as the latter to make Islam meaningful once again in the lives of the Muslims.

Qutb and Hanafi have both stressed Islam's role in contemporary politics. Both have urged action to bring about a better world. Hanafi explicitly and Qutb implicitly 
address the turāth-a word normally translated as "heritage" but which refers to the sum of contributions to the life of the Muslims by the sacred texts, along with commentaries and interpretations of these by theologians, jurists, and philosophers since the revelation. ${ }^{3}$ Yet Qutb and Hanafi differ in their approaches. The respected writer Muhammad 'Abid al-Jabiri places Qutb in the bayān tradition, meaning Qur'anic discourse that restricts itself to the use of sacred text and consensus for its message. He views Hanafi, by contrast, as belonging to the burhān tradition. Here, only perception, experimentation, and rationalism generate knowledge of the world. ${ }^{4}$

Qutb and Hanafi both ran afoul of the Egyptian government. Qutb was hanged in 1966 by the regime for allegedly advocating its forcible overthrow. Hanafi was exiled briefly between 1979 and 1982. After earning his B.A. degree from Cairo University in 1956, Hanafi spent the next decade in France, getting a doctorate from the Sorbonne in 1966. Clearly influenced by Western thought, he nonetheless sees it in crisis because of its arrant secularism. Qutb, too, was strongly influenced by Western culture, especially its literature, in the 1920s and 1930s. ${ }^{5}$ However, he later recanted all his pre-1948 writings and finds nothing redeeming in Western culture (although he accepts its science and technology).

Basically a scripturalist, meaning that he believed that meanings are inherent in sacred texts, Qutb nevertheless occasionally adopted positions that suggested the need for independent reasoning (ijtihād) and recourse to "secondary principles," such as "public interest" (mașlaha mursala), ${ }^{6}$ a doctrine invented by jurists in later years to provide guidance when the sacred texts themselves were silent. Mostly, though, Qutb held that the sacred texts were self-evident, that they are a priori truths that simply need to be invoked and implemented to solve the problems of the Muslims.

Hanafi is a left-wing phenomenologist and has served as chair of the Department of Philosophy at Cairo University. He uses the sacred texts and the numerous commentators upon them in the spirit of radical reconstruction of religious thoughtrather like Muhammad Iqbal (d. 1938). A former member of the Muslim Brotherhood, a connection he shares with Qutb, Hanafi remains sympathetic to the emotions expressed by its radical offshoots.

Qutb has had a significant impact on Arab culture and politics, especially among the youth. Inter alia, his writings introduced to Arabs the thinking of the Pakistani thinker Abu al-A 'la Mawdudi (d. 1979), especially his stress upon "divine government" (usually wrongly translated into Arabic as hākimiyyat Allāh), ${ }^{7}$ and the inimical effects of an "anti-Islamic" ( $j a \bar{h} h i l \bar{i})$ ethos in Islamic societies.

Hanafi is practically the only member remaining of the "Islamic left" (a neologism he coined), as many of his colleagues "sold out" to the Brotherhood in the 1980s and 1990s. Hanafi's break with the Brotherhood probably stemmed from his interest in using philosophy and phenomenology to develop a radical critique of tradition in ways that, to its members, probably smacked of sacrilegious tampering. Moreover, Hanafi's writings exude a sufi hermeneutic that naturally alienates most ulama and the Brotherhood. His eclecticism-phenomenology, rationalism, social democracy, critical theory, and sufism-partly accounts for the diffuseness of his writing.

Hanafi blamed Anwar Sadat for abandoning former Egyptian President Gamal Abdel Nasser's policies. His enthusiastic support for the Iranian Revolution, anathema to Sadat, led to his exile and a brief stint of teaching in Morocco and the Gulf states in the early 1980s. Though he criticized the immaturity of Sadat's killers, his 
support for their motives and feelings has alienated some intellectuals. He is primarily known for his massive, ongoing project, The Heritage and Renewal, the first installment of which is the five-volume work From Belief to Revolution. He has not generated any popular base of support, and his impact remains confined to the academic level.

Apart from concern with Islamic tradition and membership in the Muslim Brotherhood, Hanafi and Qutb have in common careers in education-Qutb in primary and secondary education and in educational administration, and Hanafi in higher education. Both also studied in the West. Both have been bitterly critical of Western imperialism, and the United States in particular. Qutb, however, was generally antiWestern, whereas Hanafi is a cosmopolitan and proud of his European ties. Both have championed the Arab masses and counted on their ability to understand their oppression and to act. Both have believed in the need to inculcate consciousness in the masses by a tightly knit group of adepts, although they disagree on the means to accomplish it. Hanafi adopts seemingly Leninist positions, whereas Qutb advocated a more traditional response: emigration to form a pious nucleus of believers that would grow through missionizing. Both have underpinned arguments with concepts whose origins are Western. Hanafi does this without apology, whereas in Qutb's case, the pattern is unacknowledged but discernible nevertheless. ${ }^{8}$

\section{QUTB'S DISCOURSE}

In the late 1940s and early 1950s, ${ }^{9}$ Qutb was engrossed in the social problems of the Arabs. A few short years later, however, he was to focus on more basic concerns. This does not mean that he was in a secular phase which he then abandoned. ${ }^{10}$ On the contrary, in this earlier phase he believed that Egyptians (Arabs, Muslims) lived in certifiably Muslim societies, and that those societies had problems that needed to be addressed and solved. His works in this period abound with such terms as consultation $(\operatorname{sh} \bar{u} r \bar{a})$, social justice (al- ${ }^{C} a d \bar{a} l a$ al-ijtim $\bar{a}^{\complement}$ iyya), mutual responsibility (altakāful al-ijtim $\left.\bar{a}^{\complement} \bar{\imath}\right)$, and equality (al-musāwāt). Qutb ardently identified with the poor and urged Arab regimes to improve their lives. This they could achieve, provided that they rejected Western and Soviet models for Islam and implemented Islamic ordinances. " These writings unremittingly reject Western cultural and social ideas and practices, and they occasionally cite disillusioned Western writers, including George Bernard Shaw and Julian Huxley. Although he resided for a couple of years in the West, Qutb did not command its languages and so relied on translations, including those by the Indian Muslim Abu al-Hasan Nadvi.

By contrast, Qutb's later writings are more "foundational." His concern was to warn against living in a state of unwitting or willful ignorance of Allah's commands (jāhiliyya). It was a short step for his followers to pronounce unbelief (al-takfir) ${ }^{12}$ upon people regarded to be behaving in such a manner. Qutb's vocabulary also included the Islamic method or system (al-manhaj al-Islämì); organic, dynamic fu-

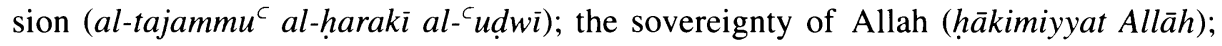
godly existence (al-kaynūna al-rabbāniyya); worship of and servitude to Allah (alcubüdiyya); exertion for the sake of Islam (jihād). In these later writings (late 1950s to mid-1960s) he reminds Muslims of their relationship to Allah. Qutb has become certain that most people claiming to be Muslims are not really Muslims. Despite his 
rejection of non-Islamic models, Qutb in fact borrowed from Western ideas in seeking to advance his scripturalist positions-especially in regard to matters of social justice. This is not to suggest that Muslims had not developed a concept of justice. Indeed, justice ( ${ }^{c} a d l$ ) is a major concept in the Islamic heritage. However, classical texts and commentaries restricted the concept within a narrow compass until the 1940s, when it suddenly made its appearance in the form of social justice.

It is also ironic that, despite his repudiation of Islamic philosophy, Qutb's own thought is suffused with organicism, one of the dominant attributes of that philosophy - which was strongly influenced by Greek organic notions. ${ }^{13}$ His works repeatedly refer to Islam as movement (haraka), vitality (hayawiyya), evolution (tatawwur), and growth $\left(n a m \bar{a}^{\supset}\right)$. Attacking philosophers who seek secular knowledge, Qutb states: "We seek the movement (al-haraka) behind knowledge." ${ }^{4} \mathrm{He}$ writes of an Islamic method (manhaj islämi) that is distinctive for its dynamism, rhythm, and touch. The metaphor of growth (physis) that is so central to Greek thought is also basic to Qutb's view of Islam, whose outlook (tasawwur) posits harmonious interaction between nature and man. Islam, for Qutb, is a system that consists of an "organic and dynamic fusion" (tajammu $u^{\subset}$ haraki $\left.{ }^{\complement} u d w \bar{l}\right) .{ }^{15}$ This seemingly means an aggregation of committed Muslims who unite their ideas and actions to worship God. The whole (tajammu ${ }^{\complement}$ ) is greater than the sum of its parts, just as a human life is greater than the sum of the body's physical structure and its mental passageways. The following passage is instructive:

Movement is one of the laws of this universe... and it is the same for the law of human existence. ... The human being's desire for movement to change and evolve reality is a ... fixed truth. It stems from the general nature of things, as embodied in the movement of primal cosmic matter ... and second from the nature of this human being. It is a requirement of his duty in the vice-gerancy on earth. ... [Islam is based on] freedom of natural growth in thoughts and feelings. ... Life and existence are not stagnant but always moving, always changing, always evolving, constantly being formed. ${ }^{16}$

Qutb approvingly cites Leopold Weiss (Muhammad Asad), a recent convert to Islam, who wrote, "History tells us that all human cultures and civilizations are organic bodies resembling living creatures that pass through all the organic stages of life." ${ }^{\prime} 7$ However, maintaining the eternity of Islam, Qutb quickly adds: "we could never say that, like other civilizations, [Islam] is subject to the passage of time and limited by the organic laws of life." 18

To summarize, then, Qutb reifies Islam, endowing it with beliefs and actions that are aggregated in an organic dynamic fusion. Islam grows and exhibits life processes. Islam is, then, an independent, functioning entity (as opposed to a collectivity of individual Muslims who decide to act in the world). Though an actor, Islam is not subject to temporal processes, including entropy. Presumably it retains its vitality because of the mechanisms of renewal that are somehow immanent in it. Among these presumably are renewal (tajdid), the application of discretion by a judge in Islamic law (istihsānn), and rulings based on public interest (mașlaha mursala). That these mechanisms are actuated by actual people in actual historical times and places would appear to undermine his reification, although this seems not to be an issue for Qutb.

Earlier, I maintained that Qutb is a scripturalist who believed that classic texts are fixed truths with fixed meanings. However, matters are not so simple. Qutb himself 
makes a point of stressing that Islam is a realistic or practical religion. Two important words for him when qualifying Islam are $w \bar{a} q i^{C} \bar{l}$ (actual, realistic) and ${ }^{C}$ amali (practical). For example, he maintains that "this religion is a serious, dynamic, practical system [manhaj camali haraki jädd]." ${ }^{19}$ He states that Islam "came to govern life in its actuality [ $\left.f \bar{i} w \bar{a} q i^{c} i h \bar{a}\right]$ and to face this actuality in order to make decisions regarding it-whether to keep, modify, or fundamentally change it." ${ }^{20}$ Therefore, he declares, "Islam legislates only for conditions that actually prevail." ${ }^{21}$ Islam "is not a theory that deals with suppositions but is a system that deals with actuality." 22 In order to make sure that he is understood in the matter of the dynamism of Islam, he declares:

Islamic society is, thus, not a fixed historical model as to its form, size, and the kind of life that prevails there. ... Islamic civilization can take various forms in its concrete structural manifestation, though the principles upon which it rests are fixed. . . The forms of Islamic civilization that rest upon these fixed principles are influenced by the degree of economic and scientific progress, because these forms make use of what in fact is found in that civilization, whatever the environment. ${ }^{23}$

What is Qutb getting at? Is he saying that the laws of Islam are eternal, but their method of implementation changes according to different historical periods? His emphasis on Islam as a practical religion seems to be suggesting so. He says that in the Meccan period (610-22), the Muslims were urged to believe, but "they did not have an actual independent life so that they could have organized themselves according to Allah's law." ${ }^{24}$ However, in the Medinan period (622-61), the Muslims were provided with the laws that they needed because, at this time, "they had an empowered state" and "laws were revealed to them, and the system was established for them that met the actual needs of Muslim society." 25

In distinguishing between the Meccan and Medinan periods, Qutb seems to imply that changes in historical time bring with them changes in the way people address Islam. But at the end of the day, this is not in fact what he believes. He actually maintains his scripturalist identity, because in the Meccan period, there were no laws to obey, just beliefs to hold. Accordingly, the way to implement the laws could not have changed across the two periods because it was only in the Medinan era that the Prophet promulgated actual laws.

Moreover, because Qutb's late writings hold that everything that had happened after 661 (except for the rule of ${ }^{C}$ Umar II from 717 to 720 ) was $j a \overline{h i l i},{ }^{26}$ it is the Medinan era that stands as the unique exemplar for contemporary Egypt of Islamic state and law. This means that one has no choice but to apply the fixed truths of the Medinan model per se (there being no other models of true Islam) if one is interested in changing the Egyptian realities of the late 20th century (or any time period after A.D. 661 , for that matter).

Furthermore, note Qutb's unit of analysis. It is "Islam" that "has come to regulate the affairs of life in their actuality." 27 It is "Islam" that "faces this actuality in order to make judgments about it with its commands." ${ }^{28}$ Thus, if one is arguing that Qutb insists on the historicity of the application of the law-according to which the method of application may vary from one era to the next-one must somehow explain why Qutb is unwilling to accept the possibility that human beings might freely wish to interpret matters in non-scripturalist ways. His reification of Islam renders it 
difficult, if not impossible, to see the role of human beings except insofar as they would today follow the model of Medina.

At one point, Qutb tries to show that the forms of Islamic society may differ while the principles upon which they rest are immutable. ${ }^{29}$ After Islam entered Africa, the natives began to wear clothes and emerged from their "doltish lethargy" to engage in energetic work. They stopped worshiping totems and prayed only to Allah. By citing this example, Qutb feels he has demonstrated the historicity of the forms of Islamic society in the context of the timelessness of Islamic values, presumably because black African societies are structured differently, say, from Arabian societies on the peninsula. But this is not persuasive. First, how can Qutb give this as an example of Islamic society if it is inevitably jāhilī? Also, in what way is his reference to central Africa's embracing Islam a demonstration of the historicity of the forms of Islamic civilization? He has not shown the manner in which the legal, political, social and economic processes and institutions of these Africans arose and vary from the legal, political, social, and economic processes and institutions of another Islamic people, while both peoples remain faithful to the eternal and unchanging principles. Qutb does not demonstrate how individuals shaped these processes and institutions in historical time. Notice how he phrased it:

Islam [sic] created civilization in central Africa among the naked people, for by its very existence it clothed bare bodies. Thus, the people entered the civilization of clothing, embraced by the Islamic orientation that was applied. Also, people began to abandon their doltish lethargy for energetic work to exploit the material treasures [of the world]. Additionally, they left the state of tribalism for the umma. They stopped worshipping specific totems and began worshipping Allah. What is civilization if not this? . . As for Islam entering into another environment, it creates through its eternal values another form of civilization, which form utilizes and fosters that civilization's existing assets and possibilities. ${ }^{30}$

Once again, it is "Islam" that "creates" or "Islam" that "enters into." True, he speaks of other forms of Islamic civilization, but it is Islam that creates these forms. If it is "Islam" that does this, and if he already has told us that nothing is Islam except the practice of the Prophet, the Medinan caliphate, and the rule of 'Umar II, then clearly he leaves us with a dilemma: the Islam of 622-61 (and 717-20) must constantly replicate itself in all environments and all historical periods if the result is to be the genuine article. If it does not, then the product is not Islam. Meanwhile, the role of human beings has been reduced to the alleged actor who is acted upon-by a disembodied Islamic "system." 31

Recapitulating, in Qutb's view the answers to the most pressing human needs over the course of changing historical time are to be found within the web of Islamic praxis (i.e., the unity of Islam's theory and practice). This is apparently so because of the flexibility he believes is evinced by Islam, as manifested by what he holds to be its dynamic quality, as outlined earlier. In short, internal to Islam are the socialresponse mechanisms to human needs. However, in truth, Qutb gives Muslims a stark choice between a reification (the model of 622-61/717-20) and jähiliyya. If all other periods are ruled out as models for law and state, then it is hard to accept Qutb's claim that while the general truths of Islam are eternal, the method of implementing the laws and regulations of Islam differ from one historical period to another. 
SOCIAL JUSTICE IN QUTB'S WRITINGS

Whereas Qutb believed that he had logically anchored his concept of social justice in the dynamic (haraki $)$ quality of Islam, his views of social justice probably emanated from notions of distributive justice of Western provenance. By this, I do not suggest that Qutb directly drew from Western writings on social justice. I argue rather that the social discourse of late-1940s Egypt, influenced by Fabian and other European currents of socialist thought, resonated with ideas of welfare, public good, and collective responsibility -in a word, social justice. ${ }^{32} \mathrm{He}$ thus appropriated the concept of social justice from this discourse and "realized" (that is, materialized) it in the sacred texts because of the importance he attached to his project of showing that Islam is superior to any system generated in the West. Ironically, this act of appropriating and "realizing" social justice in the Qur’an and sunna is further warrant for identifying Qutb as a scripturalist.

Distributive justice, with its roots in Plato and the Greeks, is embedded in the concept of natural law. The law of nature applies to a system of right or justice held to be common to all human beings. Enlightenment writers argued that natural law superseded the laws of religion and the state. Combining these considerations with notions of social contract, philosophers such as Montesquieu and Rousseau held that as individuals entered into such contracts, they did not cede their natural rights to a ruler but to society as a whole. Thus, society became the guarantor of the rights of its members to freedom, equality, and social justice. In all this, there is no accommodation of divine law.

In the Qur'anic tradition, according to 4:58, "Allah commands you to return trusts to their owners." This is usually interpreted to mean that Allah has vouchsafed to human beings, his vice-gerants, certain "deposits" or "trusts." These temporarily bestowed trusts (amānāt) include such things as knowledge and the law of God, which must be returned to Allah and the Prophet (their "owners"). By contrast, natural-law and social-contract theorists held that it is society that is the trustee and human beings who, as the trustors, have vouchsafed their deposits (i.e., their justice, freedom, equality, and pursuit of happiness) to this society. Consequently, it is society that must render the trusts to their owners - that is, to individuals. This notion is, of course, completely antithetical to the Qurªnic view, which holds Allah-not his vice-gerants - to be the trustor.

Accordingly, the Arabic term al- ${ }^{c}$ adāla al-ijtimā $\bar{a}^{\complement}$ iyya-"social justice"-is a 20th-century neologism coined by Muslim writers taking cues from ideas imported from abroad. Islamic scripture (the Qur ${ }^{\supset}$ an and sunna) simply did not reflect within its rich tradition such a thoroughly anthropocentric concept as social justice.

In the Qur'an, the noun form ' ${ }^{\supset} a d \bar{a} l a$-justice-does not appear. Instead, the root, ${ }^{c} a-d-l$, appears in the verbal perfect, imperfect, and imperative forms ('adala) $y a^{c} d i l u / i^{C} d i l$ ), and in the noun form ( $\left.{ }^{c} a d l\right)$. As a verb, it means to proportion, create in symmetry; to be just, equitable; to offer an equivalent; to swerve; to ascribe equals [to God]. In the noun form, it means counterpoise, equivalent; justice; equity. Thus, cadl in the meaning of "justice" and "equity" does appear in the scriptures but lacks a social dimension. In 2:282, the word qualifies a scribe writing down the terms of a contract in a just manner or a guardian explaining a contract in a just manner to a 
mentally deficient individual. In 4:3, believers are admonished to act justly toward orphaned girls by marrying the ones who are lawful to the Muslims in order to prevent their abuse. Later (4:129), Allah warns Muslims that they will not be able to treat multiple wives equitably and hence should marry only one. Later yet (4:135), Allah admonishes Muslims not to let lust make them swerve from justice.

At other points, Allah commands the Prophet to judge equitably among people $(a l-n \bar{a} s)(4: 58)$ or to arbitrate equitably among two warring factions (49:9). In 5:8, Allah orders believers not to let hatred for others cause them to deviate from justice and warns them to be just. The term ${ }^{C} a d l$ is also used to refer to "two persons of equity" in regard to determining appropriate compensation for killing game while on the pilgrimage (5:95); witnessing the signature of a will $(5: 106)$; or witnessing a man's divorcing his wife without violating the injunction not to do so during a woman's pregnancy $(65: 2)$.

On some occasions, the justice in question refers to Allah's words, held to be perfect in truth and justice (6:115) or deemed as enjoining justice (16:90). In 6:152, Allah commands people always to speak with justice. In 7:159, reference is made to certain followers of Moses who "show the way to the truth and deal justly in accordance with it." More generically, in 7:181, Allah says that He has "created people who lead [others] to truth and act justly in its light." And in 7:15, the Prophet is commanded to tell the faithful that he has been ordered to act with justice (or possibly with "equivalence") toward them. In a final case, the word refers to the difference between a dumb man and a man who is "just" and follows the right path (16:76).

Most of these references are to Allah's conduct; to discrete, individualized relationships among individuals involving quite specific aspects of private life, or to very abstract notions of equity in people's general behavior. In the two cases in which the arena in which justice is to be exercised seems to be a public one (4:58 and 49:9), the "social" dimension is still missing. In 4:58, the word $n \bar{a} s$ (people) is an abstract term lacking notions of corporate personality and rights that inhere when one speaks of social justice for a group in a modern sense. Instead, Allah commands that those who judge must do so "in a just manner" ( $\left.b i-l_{-}{ }^{C} a d l\right)$ toward an abstract entity referred to as "the people." In fact, Qutb's own commentary on this verse stresses that the referent of al-nās in this passage is "each individual as an individual." ${ }^{33}$ If Qutb had social justice in mind, one would think that he would try to introduce the concept of a citizenry rather than refer to atomistic "individuals as individuals." As for 49:9-arbitrating with justice in relationship to warring factions-the justice that is bespoken is akin to fair-mindedness. This is not the meaning of social justice as it is understood in the modern sense, which is a matter of a collectivity whose members share interests, constitute themselves as a corporate group, and struggle to promote those interests in the arena of civil society. ${ }^{34}$

In the sunna, the noun form ${ }^{C}$ adāla appears only once in the eight major codices of Sunni hadith. ${ }^{35}$ This lone reference is in the phrase, "for these are people of steadfastness and justice" (wa ha $\bar{a}^{\supset} u l \bar{a}^{\supset}$ ahl al-thabt wa-al- $\left.{ }^{\complement} a d \bar{a} l a\right) .{ }^{36}$ The characterization, "people of ... justice" qualifies a group of people who behave equitably in terms of accepted understandings of ethical behavior. It does not carry the connotations of a corporate unit to which accrues the legal right and standing to demand justice as a matter of the interest of the corporate whole. 
In a recent study, Toby E. Huff holds that in Islamic tradition, considerations of justice are adumbrated by reference to the "highly particularistic . . . treating all cases according to the particularities of the case and the individual . . . thereby refrain[ing] from establishing a set of uniform and universal principles of fairness and justice." As Joseph Schacht puts it: "The aim of Islamic law is to provide concrete and material standards, not to impose formal rules on the play of contending interests." ${ }^{37}$

The reason that it is important to stress this point about the silence of the scripture on the theme of social justice is that Qutb maintains that the Muslim can find everything necessary for his well-being there. ${ }^{38}$ Although Qutb occasionally refers to the $f u q a h \bar{a}^{\supset}$ of later generations to support some points that he wishes to make, ${ }^{39}$ the overwhelming majority of his references are to the Qur ${ }^{\supset}$ anic and sunna texts.

It may be maintained that justice takes on a social dimension in the writing of alGhazali (within the framework of his theory of virtue) and that, therefore, Qutb is drawing from the Islamic tradition after all. However, as Mohamed Ahmed Sherif notes, when al-Ghazali does talk about justice, his emphasis is on

justice in respect to character traits. It is true that he speaks about the religious law and the need to observe it, but justice for him is important because it is the virtue of the soul which is a sign of individual perfection, not because it has a social function. Justice brings about a harmony among the faculties of the soul, preparing the individual for superior virtues. Because of this view of justice, Ghazali does not list any virtues under justice, unlike some Muslim philosophers, such as Miskawayh. This brief description is all that Ghazali has to say about justice... . He devotes more space to other virtues and thus he shows his disagreement with the philosophic tradition in which justice, especially in its social context, occupies a high position. ${ }^{40}$

It is true that justice does, indeed, take on a social dimension in the writings of Islamic philosophy. Even al-Ghazali (who might be considered the least objectionable of the philosophers from a Qutbian perspective) did accept in passing the Aristotelian Nichomachean Ethics' concept of distributive justice-rendering this as "justice in relation to transactions" and pointing out that "the distribution of goods in the city can only be just when the ruler takes into consideration the functions of the different classes of the city as well as the natural order of things." ${ }^{41}$ But al-Ghazali does not appear to have attempted systematically to integrate the Aristotelian notion of distributive justice into his scheme of the virtue and excellence of the individual, and, indeed, it remained an ad hoc component of his Weltanschauung. Moreover, as noted earlier, Qutb rejected the contributions of Islamic philosophy because, in his view, they corrupt the intent of the scripture.

The rejoinder may be made that Islamic law permits invoking the doctrine of "secondary principles" when strict adherence to the "primary principles" of the faith might cause harm to the Muslims. Two such "secondary principles" are discretion of the jurist (istihsān) and public interest (mașlaha mursala). ${ }^{42}$ Consequently, those sympathetic to Qutb's argument could hold that even if social-justice meanings are absent in the original canonical sources, jurists writing in later historical periods nonetheless have contributed to the gradual construction of precisely such a doctrine of social justice by invoking these secondary principles in the desire to protect the life's chances-hence, distributive social justice-of the Muslims. But in fact it 
seems that it is only in the 1940s that Muslim writers take up the matter of social justice.

According to Olivier Carré, ${ }^{43}$ the concept of social justice came into currency for the first time in Sunni Islamic discourse in 1949 in the writings of Muhammad alGhazzali (who may have been the very first writer to use the term), 'Abd al-Qadir CAwda and Sayyid Qutb between 1949 and 1951. ${ }^{44}$ Recently, it has been argued that Qutb had finished the draft of his book Social Justice and Islam in 1948, although actual publication did not follow for a year. ${ }^{45}$ Qutb was to join the Brotherhood shortly, while the others were already members. (Significantly, ${ }^{\complement}$ Awdah had been trained as a lawyer in France.) If earlier jurists were adding to the corpus of legal thought that could accommodate the idea that the natural repository for "social justice" was "Islam," it is surprising that the concept did not emerge earlier than the 1940s.

In summary, social justice is absent from the Qur an and sunna. Although suspect among the jurists who have been the architects of Islamic ordinances relating to social relations, certain Muslim philosophers did accept Aristotelian notions of distributive justice in portraying the ideal individual and the ideal city. These writings remained on the margins of legal developments until the 20th century, when reformers, following the opening provided by Muhammad 'Abduh's (d. 1905) argument that reason could constitute a basis for judgment in Islamic law, sought to work out an Islamic concept of social justice. To do so, they addressed elements of social democratic theory, with its roots in the Enlightenment, Locke, Hobbes, Roman law, and the Greeks. The seeds of the concept of social justice are already to be found in the writings of Hasan al-Banna (d. 1949), founder of the Muslim Brotherhood.

\section{QUTB'S TURN FROM SOCIAL JUSTICE}

Qutb turned from the social-justice themes in his later work, perhaps because the Egyptian government-which had launched a devastating campaign against the Muslim Brotherhood-had coopted the theme of social justice for its own ideology of "democratic cooperative socialism." Increasingly, Qutb emphasized Allah's sovereignty (häkimiyyat Allāh). As earlier noted, he was influenced in this by Mawdudi, who, however. never used the term but instead spoke of "divine government." The word häkimiyya does not appear in the Qur'an in this form. However, in two key verses, judgment $(\mathrm{hukm})$ is ascribed to Allah alone (12:40 and 12:67: "inna al-hukm illa li-Allāh"). Qutb's interpretation of these verses is that the word hukm should be translated not as judgment but as rule. ${ }^{46}$ Thus, when he interprets the crucial verses in 5:44, 5:45, and 5:47, he renders the imperfect verbal form, yahkum, as rules, not judges. These verses have traditionally been interpreted as follows: "He who does not judge according to Allah's revelation is an unbeliever [5:44]/oppressor [5:45]/ ungodly [5:47]."

Hasan Hudhaybi, the Supreme Guide of the Muslim Brotherhood between 1951 and 1973, termed Qutb's interpretation of hukm and yahkum as sovereignty and rule as a heretical innovation $\left(\operatorname{bid}^{c} a\right),{ }^{47}$ insisting that the traditional rendering of "judging" and "judgment" was the correct one. Despite this, Qutb's interpretation has introduced a new element into the discussion: 
Islam is servitude to Allah alone and assigning divine characteristics to Him, the foremost of which is sovereignty (al-häkimiyya).... "And he who does not rule according to what Allah has revealed is an unbeliever." What we have said about Islam is not a heretical innovation that we have thought up. ${ }^{48}$

Accordingly, Qutb adopted a radically uncompromising stand on these verses, on the basis of which one might conclude that any Muslim who did not accept that sovereignty and rule were Allah's alone was an unbeliever. This in itself is not remarkable, but the idea that a particular individual or group could claim the right to decide whether or not others accepted Allah's sovereignty is rejected by many. ${ }^{49}$

These considerations led Qutb finally to call for the establishment of a countersociety of pious Muslims, which would be formed through their figurative and, if necessary, literal "emigration" from the surrounding godless ( $j$ a hili $)$ society. Qutb wished to create a sufficiently aware and committed core of adherents to "true" Islam. He hoped this would occur peacefully, but a coercive response by jāhili rulers and their supporters might make this impossible. ${ }^{50}$

\section{HASAN HANAFI'S PROJECT}

As noted, Hasan Hanafi had also been a member of the Muslim Brotherhood. His studies at the Sorbonne, where he obtained the doctorate in 1966, exposed him to arguments of the left (socialism and Marxism), as well as to various scholarly approaches to knowledge, including phenomenology, rationalism, and critical theory. Phenomenologists believe that knowledge comes from the apprehension of phenomena by direct investigation and through a formal description of their structure, without recourse to theoretically based causal explanations. But causality is a significant concern in the burhān tradition, a category into which Jabiri places Hanafi, as was earlier indicated.

Hanafi intended his journal, The Islamic Left (al-Yasār al-Islāmī), to be a successor to the 19th-century al- ${ }^{\complement}$ Urwa al-Wuthqā, founded by Muhammad 'Abduh and Jamal al-Din al-Afghani as a vehicle for the Islamic critique of Western civilization. Sadat's September 1981 crackdown on domestic opposition groups meant that he could publish only one issue of this journal.

Hanafi believes that Qutb would have become a member of the "Islamic Left" had he lived. ${ }^{51} \mathrm{He}$ is sympathetic to much in Qutb's perspective, both praising him $^{52}$ and accepting many of Qutb's premises, including, for example, the belief that Islam was the first socialist religion. ${ }^{53}$ Hanafi maintains that Qutb's apparent extremism stemmed directly from his torture. However, as Abu Zayd notes, this would not explain why others such as Mawdudi, who had never suffered torture, adopted similar positions. Hanafi, however, takes significantly different positions from Qutb, especially in regard to the importance of philosophy and rationalism in human history and society. Whereas Hanafi speaks of the "enlightened thinker" and "enlightened reason," Qutb insists on "servitude" ( ${ }^{c} u b \bar{u}$ diyya) and warns against the danger of secularism that lurks insidiously in the interstices of rationalist discourse.$^{54}$ Hanafi could not disagree more. In a forceful passage, Hanafi wonders: 
There is no doubt that if we wanted to get into a bidding competition in regard to belief and defending Allah, razing [the edifice of] reason and cancelling out the human being, we would say that Allah rules over the mind and that the mind is the object that is governed; that Allah is the creator of it, the possessor of all things, the ruler of all things. But where can the danger be? What is the situation in which we find ourselves? Is Allah in danger? Or is reason? Do we defend Allah's hākimiyya or the hăkimiyya of reason? Are we defenders of Allah or are we human beings defending human rights? It may be that the human being, in the presence of this bidding competition, will keep silent in fear of the coercion of the masses, the weight of history, and the attack of the rulers. However, defending the rule of reason is the task of our generation, defending the rights of the people $[a l-n \bar{a} s]$ and employing their minds. ${ }^{55}$

Hence, not surprisingly Hanafi disagrees with Qutb's implicit requirement that "true" Muslims pronounce unbelief (takfir) upon "false" believers. One of Hanafi's major goals is to transcend mutual recriminations in regard to pronouncing unbelief and apostasy upon people. ${ }^{56}$ Hanafi's own purpose is the reconstruction of Islamic civilization, a task he assigns to himself. In a remarkable comparison, his publisher maintains that Hanafi's project is comparable to Ibn Khaldun's examination of the rise and fall of civilizations for the purpose of regenerating Islam. ${ }^{57}$ One finds a certain instrumentalism in Hanafi insofar as his treatment of the turäth is concerned. Seemingly, he wants to fashion the turāth into an ideology. As such, this turāth becomes a repository from which to draw ideas and deploy them as weapons to stake out interests in historical time and place. ${ }^{58}$

Hanafi wants to reconstitute the tradition of the ancestors (al-salaf) so that the human being and history are placed at the center of concern. "The Science of the Principles of Religion" ( starts, ends, in Hanafi's scheme, with "The Human Being and History" (al-Insān wa $\left.a l-T a^{\supset} r i k h\right)$. It would appear that this bifurcation is based on ideal types, with the former representing the experience of Muslims at the formative stage of their religion, and the latter reflecting the contemporary good Muslim liberated from the negative accumulations of deadly imitation. Hanafi calls "The Science of the Principles of Religion" ("Ilm Ușūl al-Dīn) "general history” (al-Ta ${ }^{\supset}$ rikh al- $\bar{A} m m$ ); by contrast, he calls "The Human Being and History" (al-Insān wa al-Ta'rīkh) "particular history" (al-Ta ${ }^{\supset}$ ikh al-Muta ayyan). Here is how he distinguishes between general and particular history:

After general history, which is manifested in Prophecy and the Day of Judgment-that is, in the past of human-kind and in its future-appears special or particular history, which is manifested first of all in theory and action.... Whereas general history was the creation of Allah, since it is He Who sends the prophets and calls the people to Him on the Day of Judgment, particular history is the creation of the human being. For theory and action are individual, human categories; similarly, rule and state are discretionary human social systems. General history is materialized only in particular history. ... [T] he Divine Project as it was completed in the Revelation as Divine Knowledge can only be materialized through the theory and practice of the human being and the rule and system of the community. It is in particular history that the Science of the Principles of Religion is concluded, the Revelation of the Divine Will is achieved, beliefs are established, and order is perfected. ${ }^{59}$

Abu Zayd provides a chart (Table 1) purporting to show Hanafi's reconstruction of Islam, one that features the juxtaposition of classical concepts with their anthropo- 
TABLE 1 Hanafi's reconstruction of Islam

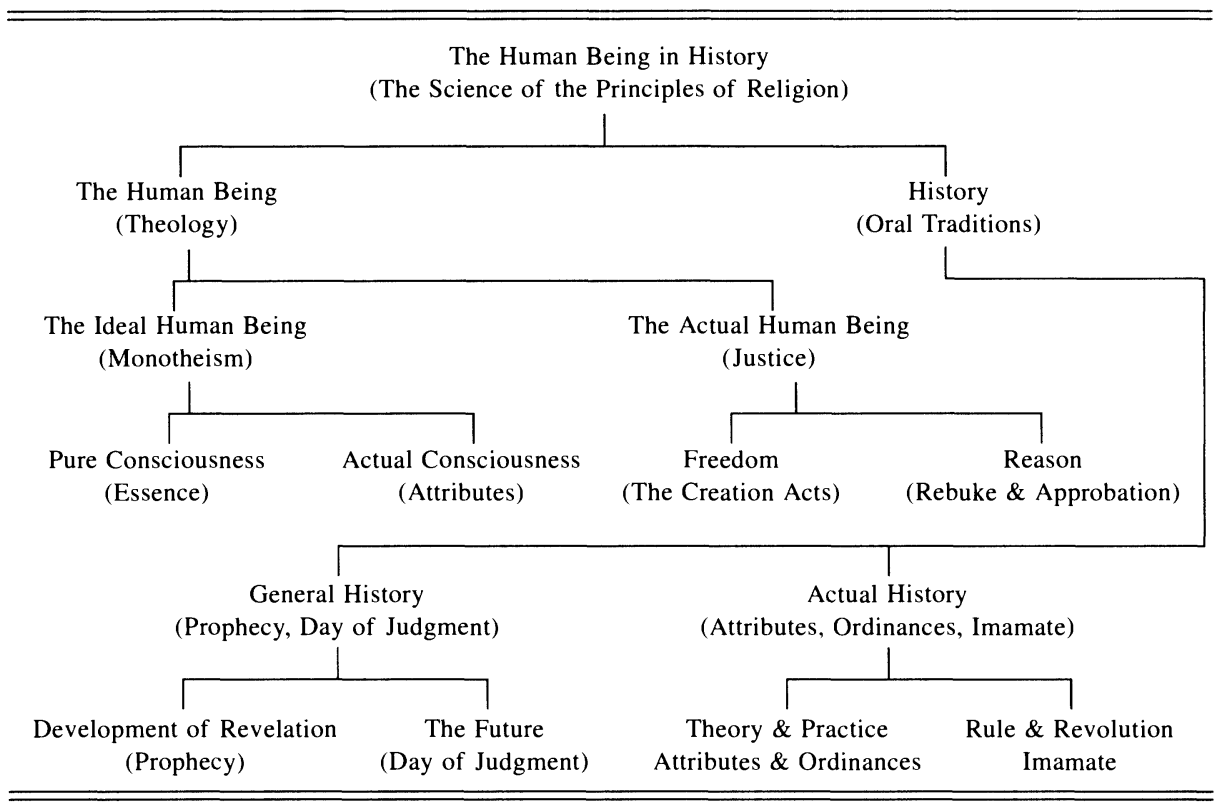

Science of the Principles of Religion, Cilm uṣūl al-dīn; Theology, al-ilāhiyyāt; Oral Traditions, alsam $^{\complement}$ iyyāt; Monotheism, al-tawhīd; Justice, al-' ${ }^{\complement}$ adl; Essence, al-dhāt; Attributes, al-șifāt; The Creation \& Acts, al-khalq wa al-af ${ }^{\complement} \overline{a l}$; Approbation \& Rebuke, al-tahsin wa al-taqbih ; Prophecy \& Day of Judgment, al-nubuwwa wa al-mī $\bar{a} d$; Ordinances \& Imamate, al-aḥkām wa al-imāma.

centric and historicized counterparts. In the chart, the classical concepts are put in parentheses, and their anthropocentric and historicized analogues are presented above those concepts. ${ }^{60}$

In Hanafi's view, the original subjects of 'Ilm Ușull al-Din include oral traditions (al-sam ${ }^{\complement}$ iyyāt); the religious sciences (al-ilähiyyāt); the oneness of God (tawhìd); the essence, attributes, and names of God (al-dhät, al-sifät, al-asma $\left.\bar{a}^{\supset}\right)$; the contingency of human action (iktisāb); prophecy (nubuwwa); the day of judgment ( $\left.m \bar{\imath}^{\complement} \bar{a} d\right)$; the ordinances of religion $(a h k \bar{a} m)$; and the imamate (imāma). Through human reconstruction - that is, as a result of human beings living their lives in actual historical timethese classic concepts become transformed into spatial and temporal qualities: the ideal and the actual human being, pure consciousness, particular consciousness, freedom, reason, general history, particular history, theory, practice, rule, and revolution. The reconstructed forms, of course, are produced not only through human agency but also by human beings who are fully conscious of what they are doing. Without this transformation of the classical concepts of Islam, which can be effected only by people actively mediating them through their concrete historical experiences and struggles, Islam will remain simply an idealization that will never be actualized in human communities.

Put in the context of Qutb's thought, this perspective is striking. Qutb wanted somehow to make real for every late-20th-century Muslim Hanafi's "ideal type" of 
general history. In contrast, one might say that Hanafi's "unit of analysis" is the individual human being living in actual historical time. He would admonish that Qutb's project, despite references to Islam as a practical religion, abstracts the human being from the world in which he lives in the effort to make that individual the pious factotum of divine will.

Generally speaking, Hanafi is impatient with the failure of modern Islamic intellectual and social movements to unite their calls for action with a sound analysis and theoretical foundation. It is no good to call for action to restore the excellence of Islamic society if one does not undertake a critique of Islam itself. Hanafi and Qutb clearly part company on this important issue. Qutb assumes as given and unproblematical a number of the characteristics that Hanafi wants critically to analyze. Here is how Hanafi puts it:

Modern [Islamic] reform movements have substituted action for theory, persisting in calling for [action] for more than one and a half centuries. ... Is it possible to call for action without a theory of action? Is it possible to change without a theory of change? . . . Thus, reform [efforts] have remained [at the level of] mere preaching, giving guidance, goading the people to action. But the people do not act on the basis of preaching but rather by . . . changing their conception of the world. Therefore a return to the establishment of knowledge and transforming unity into theory are the path to radical reform. The transition from reform to revolution is first of all firmly rooted in the consciousness of the masses, which provides them with a revolutionary conception of the world before the revolution occurs in fact. The theory of knowledge is the necessary ideological edifice for the revolution of the masses. ${ }^{61}$

Hanafi maintains that early Muslims knew the importance of theory as the basis of all action. ${ }^{62}$ These adepts worked through the complex of ideas that was raised before them by the Prophet-not in some abstracted manner, divorced from the historical conditions in which they lived, but, on the contrary, by reference to these conditions. In this manner, early Muslims did not consider Allah as a mental construct to be confirmed or disconfirmed. In a remarkable passage, Hanafi says that for them,

Allah is a project of humanity [mashrü $\bar{u}^{c}$ al-insäniyya] the realization of which this humanity has tried to effect from its inception until now. Allah is the progress of history in the creation of which human beings have a share. Allah is not a subject whose existence can be rationally proved but rather is history which progresses, reality which moves, and masses who make revolution. ${ }^{63}$

Qutb would surely reject this assessment of Allah as somehow subsumed in human history. He would hold that it is a classic case of jahili $\bar{l}$ thinking, the more inimical to the Muslims' interests because it is advanced by one whom he would regard as a nominal believer.

But for Hanafi, any other interpretation is a prescription for continued stagnation. Unfortunately, he maintains, this patent historicity of Islam and the role of the Muslims eventually became undone in favor of a perspective that abstracted the faith and its believers from the world of reality into some hypostatization. How did things reach this pass? Why is it that, as Hanafi sees it, Muslims are unable to understand their situation in ways that will enable them to generate creative solutions to their present problems? The short answer is the "tyranny" of Ash carite ontology and epistemology, which, despite its $\mathrm{Mu}^{\mathrm{C}}$ tazilite contenders, sealed its victory through the efforts of the 
great Abu Hamid al-Ghazali (d. 1111). ${ }^{64}$ Ash ${ }^{c}$ ari authoritarian control over the shari ${ }^{\mathrm{C} a}$ in the service of the ruling classes can be ended only by a constructive critique of the entire "heritage." Otherwise, spontaneity by itself, as the left has long argued, can achieve only so much.

For Hanafi, contemporary Arab society is divided into two parts, one represented by the movement known as the salafiyya, the other by secularism. He sees his contribution to overcoming their sterile confrontation as freeing the salafis from their rigid orientation toward the past $\left(i t t i b \bar{a}^{\complement}\right)$, and as reforming the reprehensible innovations $\left(\right.$ bid $\left.^{c} a\right)$ of the secularists. ${ }^{65}$

Hanafi believes that the "heritage" is the basis of contemporary awareness in society and calls it the "psychological storehouse" of the masses. In focusing on the elements of the "heritage" that are in need of "renewal" (tajdid) Hanafi is motivated by the needs of the present. For Hanafi, the "heritage" by itself has no inherent value. Its worth is measured by being the source for generating a scientific theory of action that can be put to use for the individual's benefit. This seems somewhat like secularism, but secularism interests itself in human progress without regard to religious knowledge and experience, a disregard that Hanafi, of course, rejects. Here is how he puts it:

Our faith [is] in the heritage and its renewal [al-turāth wa al-tajdid] and the possibility of solving the crisis of the [present] age ... and the possibility of reconstructing the heritage to give the [present] age a new push forward. The heritage . . . is a psychological storehouse for the masses and the theoretical foundation for the structure of reality. ${ }^{66}$

Hanafi's purpose is to link contemporary values and concepts with those of the heritage. But he does not really analyze the historical evolution and crystallization of those values and concepts in the past or the present age. How have people come to absorb particular values in their consciousness in historical time, past or present? He accepts it as a given that certain values came to be held in earlier years. Seeing similar values in the present age, he concludes that the latter emanate from the former. He declares that his research "attempts to unite "the heritage and the renewal" " and holds that "the historical roots of the crises of the [present] age [are] in the old heritage, reading the past in the present and seeing the present in the past." 67

Every era, he notes, shapes its culture and its conceptions. The conceptions of the ancestors (al-salaf) were purely historical ones, expressing the realities of their time and level of culture. The same process is at work in the contemporary period. But the two processes do not operate in mutual isolation. The relationship between them is a dialectical one of nonconnection and connection. Hanafi says that we necessarily start from our own time period and look back on our past. In doing that, we find in our past the reasons for our current problems, for the decline and breakdowns that we are currently witnessing. "It is as though we choose from the old only what we want." ${ }^{68}$

Thus, Hanafi seems to be proposing a rather pragmatic course: select from the heritage those elements that seem to make sense and are also relevant for current problems. If we do this, then we can avoid trying to achieve the impossible, returning to a golden age in wholesale fashion. What is to ensure that Hanafi's process of selection does not become unmanageable? He presumably would maintain that one would be 
guided by the categories of 'Ilm Ușül al-Din, and not by phenomena divorced from that theological foundation. Those categories, as noted earlier, include oral traditions; the religious sciences; the oneness of Allah; the essence, attributes, and names of Allah; the religious ordinances; the contingency of human action; prophecy; day of judgment; and the imamate. But that still leaves the scope for choice rather wide. Contemporary problems in Islamic societies include illiteracy, hunger, poverty, overcrowding, maldistribution of wealth, and authoritarian rule. What aspects of kaläm can one draw upon to confront and begin to solve some of these problems? Moreover, who is to do the selecting?

Yet the process is not totally ungoverned, Hanafi maintains. In his view, the movement from the present to the past, which he characterizes as an "ascending movement," is mediated by what he calls the "psychological storehouse" of the masses. By this, he seems to mean that the ordinary Muslim has a certain stock of appreciation and understanding of the heritage as he or she looks back on the past for guidelines for current behavior. On the other side of this is the movement from the past to the present, which he characterizes as a "descending movement," and it is mediated by what he terms "consciousness" $\left(s h u^{c} \bar{u} r\right)$.

To summarize this, then, as the Muslim moves back in time, he or she draws on his or her "psychological storehouse" of values and symbols, based on his or her understanding of that heritage. Then, armed with the appropriate elements of the old kalām, he or she moves forward in time toward the present again. This time, though, instead of drawing upon his or her psychological storehouse, he or she applies his or her perceptions and awareness of current-day problems in terms of the model solutions that the elements of the heritage with which he or she is armed can provide. It is this supposedly dynamic process-seeing the relevance of the past for the present and projecting the problems of the present into the past-that will allow Muslims finally to address and solve their most pressing concerns.

Hanafi boldly asserts that the tragedy of the Muslims lies in a mechanical following of the models of the past. His solution is the "Islamic left," whose discourse, he believes, derives from human reality and history, not some disembodied, abstracted sacrality ( qadāsa) existing outside of history. According to Hanafi's line of argument, the heritage is not a cluster of fixed theoretical truths. Truths become such only in specific times and places. The "heritage" is thus the sum of the validations (tahaqqu$q \bar{a} t)$ of these theoretical truths in specific historical times and places, validations effected by the behavior of individuals. This being so, then the old truths are always subject to reevaluation at later historical times and places. Here, he feels, is Islam's mechanism for genuine change and renewal. Too many people say "Let us return to the past." Hanafi avers, "Let us use the past to understand the present but abandon those aspects of the past that are not relevant, replacing them with truths whose foundations may be in the past but which otherwise are put in the service of present needs."

If Qutb says "let us return to the pristine Islam," Hanafi's rejoinder is "the renewal of Islam is the solution." Hanafi criticizes scripturalists who believe that the truth is in the texts. He maintains that meanings are not inherent in texts but are attributed to them by actual human beings. ${ }^{69}$ Yet human beings can renew Islam only in con- 
crete interaction with their own historical time, and Hanafi would appear to need to show how this interaction takes place and with what results.

For example, suppose Hanafi tells us that more democracy, as embodied in the concept of "consultation" $(\operatorname{sh} \bar{u} r \bar{a})$, is needed in the present to solve some of the problems of society. He tells us this because, in his opinion, in the early years of Islam one could find the roots of democracy in the shüra idea. Yet he avoids showing how the roots of democracy actually were developed in those early years through a close historical analysis of groups, movements, and ideas. Did shūrā indeed evolve from a struggle of people in specific circumstances, or is shürā something that is counseled by Allah and the Prophet for the purpose of a fuller understanding of Allah's laws? If the latter, then it does not have much to do with democracy. If the former, then it is necessary for Hanafi to provide the specifics of the historical struggles that led to the understanding of shürā in more than a purely divine, revelational context. One cannot simply look at texts (the Qur ${ }^{\supset}$ an and sunna) in that early period from a contemporary perspective and find "democracy" in the texts. For that is tantamount to abandoning the historicity of texts.

Similarly, it could be that the value of equity - for example-pertained to ethical injunctions to be upright in relations with Allah, one's family members, and neighbors by not dissimulating to them. According to this view, too much wealth in the hands of one person could greatly complicate one's chances of being upright in relations with one's God, family members, and close neighbors. Yet stated as such, this has nothing to do with equity at the community level. What Hanafi wants to do is discover in the heritage the value of equity and use it to solve the problem of pervasive poverty in Egypt today. But to do this, he would have to show that the value of equity was used in this way by the early Muslims. To do that, in turn, Hanafi needs to show us how people in the early period struggled with one another at given historical junctures to vindicate the idea that equity in the early period conveyed the sense of obligations by putative citizens of the community to arrogate to that community as a social unit the authority and legitimacy to redistribute wealth in defense of its interests as a corporate whole against contending and competing interests. Hanafi cannot simply assume that this orientation to equity inhered in early times and so can be culled from the past and applied in the current period.

To be sure, Hanafi says that his method avoids these problems and takes into account that those early texts came to be written in historical time and place. This implies that comprehending them requires an understanding of the forces that went into their production. However, he does not seem to provide a historically grounded analysis of this sort. What is missing is an explanation of people's behavior and ideas in concrete historical junctures and in interaction with social, economic, and political groups, movements, and institutions. Hence, he may ironically be said to have committed the same error of ahistoricity of which he accuses the scripturalists.

Hanafi's dialectic of change is abstract and diffuse. The same is not true of his outline of action on behalf of that change. It is true that he has a rather utopian objective for the "Islamic Left" - to awaken the Muslims and achieve a revolution through a scholarly critique of the heritage. ${ }^{70}$ But when contemplating the actual implementation of a revolution, he raises aloft the familiar banner of the left. Borrowing a page 
from Marx's Theses on Feuerbach, he writes that Islamic reformers have basically tried merely to understand the world, whereas it is now important to change it. ${ }^{71}$ However, in order to effect such a change, one cannot rely only on ideas. Ultimately adopting a Leninist position, he declares that it is important to establish a revolutionary party organization for mass mobilization. Once a leadership is established for this organization, it will engage in raising the consciousness of the people. This eventually will be followed by armed struggle for full liberation from colonialism, feudalism, and other evils. Again in rather utopian manner, he insists that the party will truly represent the masses, not a particular class or group. In colorful terminology, Hanafi maintains that this party is the "caliph of Allah's chosen people." 72

Qutb's view of the dynamic of the revolution is somewhat similar. He, too, speaks of a revolutionary "leadership" (qiyāda), ${ }^{73}$ which has distinct leftist connotations. However, Qutb stops short of advocating a political party, contenting himself with the notion of emigration and establishing a countersociety on the periphery of existing jähili society. Once sufficient numbers have come over, the process of total transformation to Islamic society will occur, peacefully if the state does not react with coercion-although Qutb was virtually certain that the state would use forceotherwise through violence.

\section{CONCLUSIONS}

Sayyid Qutb and Hasan Hanafi represent two important currents of contemporary social thought in Egypt. Many of their concerns are similar, including a profound attachment to and concern with the turäth of Egyptians, Arabs, and Muslims. While Qutb may be termed essentially a scripturalist, believing that sacred texts convey inherent meanings in an ahistorical fashion, Hanafi maintains that the meaning of texts depends on their interpreters and hence on the consensus of each generation.

Qutb rejected rationalism and philosophy more generally because, in his view, it departed from the religious attitude and from religious commitment. Hanafi championed the application of reason as the only way for Muslims today to come to grips with their most pressing problems. Qutb reified Islam and attributed to it qualities of vitalism, growth, and power. Hanafi sees things differently, believing it more constructive to take not "Islam" as his unit of analysis but Muslims living in concrete historical periods.

Yet Hanafi's method of seeing the past in the present and projecting from the present into the past seems to short-circuit historically grounded analysis after all. He concludes that Muslims can choose from their heritage what suits them in solving the problems of today. But it is not clear that in doing so they indeed will be choosing aspects of the heritage that resonate with the actual requirements of Muslims living in the modern period, because he does not really provide us with an analysis of how values of the past came to acquire specific meanings, in actual historical time and place, for the people of that time. Let us recall that Hanafi's whole project rests on demonstrating the relevance of historical context for the significance of values. If he does not demonstrate this for the past, whence these values derive, how can he be confident about their applicability for modern historical contexts? 
Qutb's discourse does not permit the selective choosing from aspects of a putative heritage. He would insist that Islam must be taken or rejected in its entirety. For him, of course, there can be no choice between these two alternatives. The very idea of social engineering of the sort implied in Hanafi's scheme is anathema to Qutb. Yet Qutb is just as affirmative and positive in his outlook as Hanafi is that Muslims have the model solutions to their problems near at hand. Both view the future with optimism. It is just that Qutb believed that Islam, which he reified, is indivisible.

Qutb, at least in the early 1950s, emphasized themes of social justice. That he was borrowing a concept that emerged in a Western context is clear enough, but he would of course deny that and stress that social justice is rooted in the enormously rich legacy of Muslim writings on the concept of ${ }^{c} a d l$. There is nothing wrong with making social justice one of the pillars of one's analysis. But Qutb's insistence that the concept inheres full-blown in Islamic scripture is not tenable. Moreover, analysis of this issue shows that discourses as apparently different as those of Muslims and non-Muslims penetrate one another in subtle and important ways. ${ }^{74}$

For Hanafi, it is important, in vindicating "Islamic" ends, to borrow as much from the heritage of the past as is suitable but then to supplement this with concepts and ideas from outside that heritage. Hanafi feels no constraints about analyzing his society through philosophical lenses that are shaped by the major intellectual movements of the 19th and 20th centuries, beyond the boundaries of the umma.

As for practical results, both take a revolutionary position. For Qutb, the model solutions to the problems confronting the Muslims today revolve around a rejection of the society in which they find themselves, a figurative and even literal migration from such a society, and the construction of the bases for a countersociety of piety and social action. For his part, Hanafi believes that his radical and recondite reconstruction of the heritage will be understood by the masses, and when that happens, they will be ready for mobilization. Bringing this to pass, however, will require a nucleus of dedicated leaders, whose task will be to inculcate the appropriate theoretical perspective and then lead the masses into action. Although both projects strike one as utopian, it may be premature to voice such a verdict, particularly - as both writers so frequently have declared-in light of the failure of liberal, corporatist, socialist, and Marxist models over the last century.

\section{NOTES}

Author's note: I am grateful to my colleague Roxanne Euben for her comments on an earlier draft of this paper, some of which have been taken into account in the present version.

${ }^{1}$ To Professor Serif Mardin belongs the credit for explicitly identifying this dialectic and organizing an international conference on it in Washington in 1989.

${ }^{2}$ Ibrahim M. Abu-Rabic, Intellectual Origins of Islamic Resurgence in the Modern Arab World (Albany: State University of New York Press, 1996), 92-219. Unfortunately this work appeared too late to be used for this study. Leonard Binder, Islamic Liberalism (Chicago: University of Chicago Press, 1988), 170-205; Muḥammad Ḥāfiẓ Ḍiyāb, Sayyid Qụ̣b: al-Khiṭāb al-Dinī wa al-Idiyūlujiyya, 2nd ed. (Beirut: Dār al-Ṭalī a, 1988); Yvonne Haddad, Contemporary Islam and the Challenge of History (Albany: State University of New York Press, 1982); idem, "The Qur'anic Justification for an Islamic Revolution: The View of Sayyid Qutb," Middle East Journal 37, 1 (Winter 1983): 14-29; idem, "Sayyid Qutb: Ideologue of the Islamic Revival," in Voices of Resurgent Islam, ed. John Esposito (New York: Oxford University 


\section{Shahrough Akhavi}

Press, 1983), 52-70; 'Adnan Musallam, "Sayyid Qutb and Social Justice," Journal of Islamic Studies 4, 1 (January 1993); Ahmad Moussalli, Radical Islamic Fundamentalism: The Ideological and Political Discourse of Sayyid Qutb (Beirut: AUB Press, 1992); Gilles Kepel, Muslim Extremism in Egypt (Berkeley: University of California Press, 1993), 36-69; and W. Shepard, Sayyid Qutb and Islamic Activism (Leiden: E. J. Brill, 1996).

${ }^{3}$ Indeed, turäth involves not just sacred texts and commentaries on them but, in general, the whole legacy of the sacred and the nonsecular, including philosophy, literature, science, and popular culture. Turāth does not appear frequently in Qutb's writings. His concerns are better captured by concepts such as al-tasawwur al-islämi, which, however, does cover some of the "terrain" of turäth as defined earlier, especially the sacred texts.

${ }^{4}$ Jābirī, Naqd al- ${ }^{C}$ Aql al- ${ }^{C}$ Arabi, vol. I: Takwin al- ${ }^{C}$ Aql al- ${ }^{C}$ Arabi (Beirut: Markaz Dirāsāt al-Waḥda al- ${ }^{C}$ Arabiyya, 1991), 103; and ibid., vol. II: Binyat al- ${ }^{C}$ Aql al ${ }^{-}$Arabi (1990), 383-84.

${ }^{5}$ Haddad says that Qutb's fascination with literature and interest in Western culture was shaped by 'Abbas al-'Aqqad prior to the latter's turn to purely Islamic themes; Haddad, "Sayyid Qutb," 69.

${ }^{6}$ According to Khadduri, mașlaha is a term of jurisprudence that, strictly speaking, means "utility," as opposed to madarra or mafsada ("injury"), but generally, it denotes "welfare" and has been used by jurists in the modern period to mean "general good" or "public interest." See Majid Khadduri, Encyclopaedia of Islam, new ed., vol. VI, fascicules 109-10 (Leiden: E. J. Brill, 1989), 738-40, s.v. "Maṣlaha." On maṣlaḥa mursala, Qutb quotes at some length Shaykh Muhammad Abu Zahra, Professor of Shari ${ }^{\complement} a$, Faculty of Law, Cairo University in the late 1940s, who said that it is an interest for which no specific text exists but agreement over the necessity of which has been established among the jurists. See al- ${ }^{C}$ Adāla al-Ijtima $\bar{a}^{C}$ iyya fi al-Islām, 9th ed. (Beirut: Dār al-Shurūq, 1983), 119 ff.

${ }^{7}$ It appears that Mawdudi never wrote in Arabic, so his Arabic-language translators took some liberties. Thus, his phrase, hukūmat-i ilāhiyya (lit. divine government) has been inaccurately translated as häkimiyyat Allah (divine sovereignty). These are not identical terms. Thanks to Seyyed Vali Reza Nasr for confirming my view in this matter.

Certainly, Qutb's $M a^{c} \bar{a}$ lim is replete with the phrase häkimiyyat Allāh. In various of his writings, the Egyptian Muhammad 'Amara wrongly attributes to Mawdudi the phrase al-hākimiyya al-ilāhiyya. See, for example, his article "Takfir al-Muslim," in al- ${ }^{\complement}$ Arabi (Kuwait), no. 335 (October 1986), 16-20. And on Mawdudi's influence on Qutb, he declares: "Essentially, Sayyid Qutb's position on the theory of divine sovereignty [al-hākimiyya al-ilāhiyya] does not differ from that of Mawdudi." But later, 'Amara seems to contradict this statement when he says that Qutb took the idea much further than Mawdudi had by regarding not just contemporary societies with Muslim populations to be jāhili but virtually all historical cases of Islamic society, save in the periods of the Prophet, the Rightly Guided Caliphs, and the short period of the caliphate of ' Umar ibn ${ }^{\mathrm{C}} \mathrm{Abd}$ al- ${ }^{\mathrm{C}} \mathrm{Aziz}$ (717-20); 'Amāra, al-Sahwa al-Islāmiyya wa al-Tahaddi al-Hadāri (Cairo: Dār al-Shurūq, 1989), 149, 152-53.

${ }^{8}$ See Shahrough Akhavi, "Sayyid Qutb: The Poverty of Philosophy and the Vindication of Islamic Tradition," in Cultural Transitions in the Middle East, ed. Serif Mardin (Leiden: E. J. Brill, 1994), 130-52.

${ }^{9}$ Hasan Hanafi believes that Qutb's writings can be divided into four periods: (1) literary writings (1930-50); (2) social writings (1951-53); (3) philosophical writings (1954-62); (4) political writings (1963-65). See his "Āthār al-Imām al-Shahīd Sayyid Quṭb 'alā al-Harakāt al-Dīniyya al-Mu'āṣira," in al-Dīn wa al-Thawra fi Mișr, vol. V: al-Harakāt al-Diniyya al Mu`āṣira (Cairo: Maktaba Madbūlī, 1988), 167-300. For a somewhat different periodization of Qutb's life from that of Hanafi, see Haddad, Contemporary Islam; and for yet a third periodization, see Diyāb, Sayyid Quṭb.

${ }^{10}$ Qutb's secular phase lasted from the 1920s to about the end of World War II. He abandoned his secularism thereafter. However, his work in the late 1940s and early 1950s was not so adamantly concerned with the fundamentals of the faith as it was to become after his prison experiences, which began in the mid-1950s and lasted until the end of his life.

${ }^{11}$ Qutb pursues these themes in al-'Adâla al-Ijtimā ${ }^{c}$ iyya fi al-Islām (Cairo: Lajnat al-Nashr li alJāmi ${ }^{C}$ iyyīn, 1949), and $M a^{\complement}{ }^{\complement}$ rakat al-Islām wa al-Ra ${ }^{\supset}$ smāliyya (Cairo: Dār al-Kitāb al- ${ }^{\complement}$ Arabī, 1951); al-Salām al- ${ }^{C}$ Alamī wa al-Islām (Cairo: Dār al-Kitāb al- ${ }^{C}$ Arabī, 1951); and Dirāsat Islāmiyya (Cairo: Maktabat Lajnat al-Shabāb al-Muslim, 1953).

${ }^{12}$ It is true that the concept of takfir and its verb form, kaffara, is implicit in Qutb's writings. He seldom seems to have used the words directly, though it seems a logical step for his followers to do so- 
as they have-in view of his denunciation of virtually all previous Islamic societies, save those of the Rightly Guided Caliphs and the rule of ${ }^{\mathrm{C}} \mathrm{Umar}$ ibn ${ }^{\mathrm{C}} \mathrm{Abd}$ al- ${ }^{\mathrm{C}} \mathrm{Aziz}(717-20)$ as jāhili and mushrik.

${ }^{13}$ I am not suggesting that Qutb's organicism comes from his reading of Greek philosophers, merely that despite his repudiation of Greek philosophy, he cleaves closely to an aspect of Greek thought that had a profound influence on Muslim philosophy. Probably, Qutb's own organicism can be traced partly to Muhammad Asad, a convert to Islam whose original name was Leopold Weiss. This can be seen from the citation from Weiss that appears earlier. In fact, according to Haddad, Asad was a crucial influence on Qutb in the 1950s. See Haddad, "Sayyid Qutb," 70. For caution regarding the importance of external influences on Qutb, see Ibrahim M. Abu-Rabi ${ }^{c}$, Intellectual Origins of Islamic Resurgence in the Modern Arab World (Albany: State University of New York Press, 1996), 139.

${ }^{14}$ Quṭb, Khașā $\bar{a}^{\supset}$ al-Tașawwur al-Islāmì wa Muqawwimatuhu (Cairo: Dār Iḥyā̄ al-Kutub al- 'Arabiyya, 1962), 52-53.

${ }^{15}$ Qutb, Ma álim fi al-Tarīq, 2nd ed. (Cairo[?]: Maktaba al-Wahba[?] 1964[?]), 37.

${ }^{16}$ Quṭb, Khașa $\bar{a}^{\supset} i s, 46,84-85,100$.

${ }^{17}$ Ibid., 102.

${ }^{18}$ Ibid., 103.

${ }^{19}$ Quțb, Ma ālim fi al-Tarīq, 32.

${ }^{20}$ Ibid.

${ }^{21}$ Ibid.

${ }^{22}$ Ibid

${ }^{23}$ Ibid., 118-19.

${ }^{24}$ Ibid.

${ }^{25}$ Ibid.

${ }^{26}$ Qutb's attribution of jähiliyya to Islamic societies was not limited to those of the 19th and 20th centuries. In fact, he declares: "The existence of the Islamic umma is considered to have been ended many centuries ago"; Quṭ, Ma âlim fi al-Tarìq, 5. 'Amara, commenting on this passage, puts it this way: "Sayyid Qutb went beyond Mawdudi in pronouncing society to be jähili and pronouncing kufr upon it. He stated what Mawdudi had not, passing the judgment of kufr upon the umma, and not upon the society and the state He expressed this judgment with certainty, and he indeed pronounced the judgment of this umma's being in a state of kufr over the centuries"; 'Amara, al-Ṣahwa, 153.

${ }^{27}$ Ibid., 32.

${ }^{28}$ Ibid.

${ }^{29} \mathrm{He}$ puts it this way: "[Islamic values] were not the creation of history and have no intrinsic relation to time. They are a reality that came to humankind from Allah, transcending human reality and material existence"; ibid., 118-19.

${ }^{30}$ Ibid., 119-20.

${ }^{31}$ A disjuncture exists between Qutb's insistence on fixed truths and his advocacy that Muslims put at the service of their society the gains in material civilization that have taken place in jāhili society. It is certain that Qutb does not wish to turn back the technological clock. But it is not clear how technological innovations can be made to conform with the fixed truths of the 7 th century. It should be remembered that Qutb includes as part of such fixed truths that belong in the realm of Allah's guidance "human affairs, values and standards, principles and fundamentals in the political, social or economic systems and interpretation of the causes of human activity or the dynamics of human history"; Quṭ, $M a^{c} \bar{a} l i m$ fi al-Tariq , 124. For these matters, Qutb categorically forbids turning to jāhili society. Yet, one cannot simply apply advances in engineering and the physical sciences without regard to these elements, which entail complex considerations of public policy and property rights (including patents) for which 7 thcentury truths not only would not provide guidance but could present obstacles.

${ }^{32}$ Mustafa Sibac $i$, then chairman of the department of figh at the University of Damascus, wrote in 1959 that at a gathering where people were debating whether Syria could benefit from socialism, he expressed his opinion about the socialism of Islam and was rebuked by one who said: "Before word about socialism spread in Europe, none of us heard anyone call for socialism in our country. But now everyone calls for it, so that Islam has become socialist." Sibaci replied: "After we came into contact with Western civilization and began to move towards reforming our political and social affairs, it was inevitable that we would be influenced by currents of thought prevailing in the West. What's so strange about our utilizing 


\section{Shahrough Akhavi}

from the West sound methods in imitation of its influence upon our current revival." See Sibaci, Ishtirā kiyyat al-Islām (1959), 2nd ed. (Cairo: al-Dār al-Qawmī li al-Ṭibā'a wa al-Nashr, 1961), 8.

${ }^{33}$ Quțb, Fì al-Zilăl al-Qur ${ }^{\supset} \bar{n}$, 12th ed. (Jidda: Dār al- ${ }^{\complement} I l m$ li al-Tibā̄a wa al-Nashr, 1986), II:689. Qutb emphasizes that it is not just Muslims or the People of the Book but all human beings who are covered by this command. Moreover, he insists that the phrase "judge justly among the people," is a "right" (haqq) to which these same people are entitled. He adds that the "justliness" ( ${ }^{c} a d l$ ) that must characterize the judge's judgment toward the people is a "comprehensive" justliness ( ${ }^{c}$ adl shämil). In this regard, I take him to be trying to broaden the concept so that it approximates more our modern concept of social justice.

${ }^{34}$ This is not to say that later on jurists did not devise mechanisms that might be considered creating the preliminary groundwork for the construction of an understanding of "social justice" in Islamic history. The main one that needs to be mentioned is the concept of maslaha mursala-or the public interest. If one can adduce the idea that a public interest inheres, then one can proceed to maintain that one element of the public interest is the achievement of social justice.

${ }^{35}$ These codices are those of al-Bukhari, Muslim, Da ${ }^{2}$ ud, al-Tirmidhi, Malik, al-Shafic ${ }^{\mathrm{i}}$, al-Nasa ${ }^{\mathrm{i}} \mathrm{i}$, and Ibn Hanbal.

${ }^{36}$ Abū 'Abd al-Raḥmān al-Nasāài, Kitāb al-Sunan, "Ashribah," 48, as cited by A. J. Wensinck, Concordance et Indices de la Tradition Musulmane (Leiden: E. J. Brill, 1962), III-IV:155.

${ }^{37}$ Toby E. Huff, The Rise of Early Modern Science: Islam. China, and the West (New York: Cambridge University Press, 1993), 216; Joseph Schacht, Introduction to Islamic Law (Oxford: Oxford University Press, 1964), 203, cited in Huff, p. 217. Emphasis added.

${ }^{38}$ Islamists such as Qutb generally cite part of 6:38 as a warrant for this view that the Qur'an anticipated developments that occurred in later historical time: "We have left out nothing from the Book."

${ }^{39}$ For example, he uncritically accepts Ibn Qayyim al-Jawziyya's (d. 1350) reflections on relations between Muslims and non-Muslims in the context of a discussion on jihād, and Ibn Qayyim's writings on hadd punishments - for instance, in regard to theft. Despite Qutb's harsh attitudes on the "distortions" that were allegedly wreaked upon Islam after the Rightly Guided Caliphs (i.e., after A.D. 661), he actually equates ibn Qayyim's reflections on jihād and the hadd punishments for theft with "Islam." See Nașr Hāmid Abū Zayd, Naqd al-Khitāab al-Dinì (Cairo: Sīnā' li al-Nashr, 1992), 42-43.

${ }^{40}$ Mohamed Ahmed Sherif, Ghazali's Theory of Virtue (Albany: State University of New York Press, 1975), 73.

${ }^{41}$ Ibid., 72.

${ }^{42}$ It is also worth pointing out that Qutb was very cautious in regard to the role of maslaha mursala in Islamic law. Thus, he accepted the teachings of the Maliki school in this regard, rather than the more permissive Shafi ${ }^{c} i$ teachings. This is because in the Maliki interpretation, ijtihād, or independent judgment to deduce a ruling of law, is circumscribed by rather salient restrictions, whereas the Shafi $i$ school is more open and tolerant of the usage of $i j t i h \bar{a} d$ and even-in its form as al-ijtihäd al-tawfi-accords precedence to it over the text. This bespeaks Qutb's reluctance to invoke the "secondary principles" for fear of violating the categorical imperative of the sanctity of the text (nașș). See Abū Zayd, Naqd al-Khițāb al-Dinī, 67. In a way, Qutb's caution on ijtihäd in relationship to occasions for which textual stipulation appears to exist seems to be contrary to his notion-already mentioned—of Islam's "dynamic method" (manhaj haraki) and its "dynamic realism" (wāqi iyya harakiyya). In a relatively rare application of the idea of Islam as embodying a dynamic element, he maintains in perhaps his most famous work, Milestones (1964), that people must not regard each Islamic text as final. This comes in the context of his effort to refute those who claim that Islam's conception of jih $\bar{a} d$ is purely defensive. Those who maintain that it is only a defensive idea do not understand the nature of the stages through which this "dynamic system" has passed. See $\mathrm{Ma}^{c} \bar{a}$ lim fi al-Tariq , 56-57. But it turns out that virtually throughout his work, Qutb is willing to consider the changing nature of Islamic prescriptions only within the confines of the doctrine of "abrogation of one text by another" (al-nāsikh wa al-mansükh). One is therefore tempted to say that Qutb's attribution of a dynamic element to Islam occurs only when it suits his argument.

${ }^{43}$ Olivier Carré and Gerard Michaud, Les Frères musulmans: Égypte et Syrie (Paris: Editions Gallimard/Juillard, 1983), 84, 233.

${ }^{44}$ Apart from Qutb's own book, al-'Adāla, one should cite al-Ghazzālī’s book, al-Islām wa-Manāhij al-Ishtirākiyya (Cairo, 1949); and 'Awda's al-Māl wa al-Hukm fí al-Islām (Cairo/Beirut, 1951). According to Hasan Hanafi, prior to publishing his book on the subject, Sayyid Qutb had written an article in 
1949 on the matter, although this is not cited in the extended bibliography of Qutb's works attached to the end of Diyāb's Sayyid Qutb.

${ }^{45}$ Adnan Musallam, "Sayyid Qutb and Social Justice," Journal of Islamic Studies 4, 1 (January 1993): 52-70. Qutb himself used the term "social justice" in the title of an article that he published in Majallat al-Shu' $\bar{u} n$ al-Ijtima $\bar{a}^{C}$ iyya in 1944, although this was during his secular phase. Thanks to an anonymous referee for this last piece of information.

${ }^{46}$ That this is clearly a departure may be seen by the fact that in the Qur'an, the root associated with notions of rule is $a-m-r$, not $h-k-m$. He remains a scripturalist, however, despite this innovation, because he simply would say that the meaning of the text is self-evident.

${ }^{47}$ See Hudhaybi's book $D u^{c} \bar{a} t$, là Qudăt (Cairo, 1977), esp. 63, 72-73. Saying he has not found the term häkimiyya in either the Qur'an or the sunna, Hudhaybi stresses that he has no trouble with the idea that to Allah accrues all power in the universe-all Muslims must avow this. But he objects to the idea of Qutb and his followers that this principle of Allah's absolute power means that human beings cannot make any laws for the regulation of society. What is unacceptable is that a self-appointed group can apply a litmus test to others as to whether their behavior enhances or detracts from Allah's omnipotence. "This view of hakkimiyya is erroneous." Allah has given human beings the ability to write and implement laws: "Truly, Almighty Allah has left us enormous leeway in the affairs of the world."

${ }^{48}$ Quṭb, al- ${ }^{\complement}$ Adãla al-Ijtima $\bar{a}^{c}$ iyya, 9 th ed., 12.

${ }^{49}$ The standard response by the official clergy and liberal Islamists is that as long as an individual has recited the credo of the faith, the authenticity of his or her belief is a matter for Allah to decide. Several hadiths are frequently cited, including one in which the Prophet is related to have said: "I was not commanded [by Allah] to penetrate into the hearts of the Muslims." Mawdudi himself insisted on extreme caution in this area. See 'Amāra, "Takfïr al-Muslim," 18.

${ }^{50}$ For discussion of these points, see Quț, $M a^{c} \bar{a}$ lim fi al-Tariq.

51 "If [Qutb's] evolution had continued in its natural course, he would have ended with scientific socialism to correspond with Islam, and he would have become one of the pillars of the Islamic left in Egypt and one of its primary supports in the Islamic world.” See Hanafi, “Āthār al-Imām,” 219.

${ }^{52}$ Ibid., 167-300.

${ }^{53}$ Hanafi, "al-Taḍāmun wa al-Waḥda," in Hanafi, al-Din wa al-Thawra fi Miṣr, 1952-1981, vol. IV: Al-Dìn wa al-Tanmiya al-Qawmiyya (Cairo: Maktaba Madbūlī, n.d.), 110, $116 \mathrm{ff.}$

${ }^{54}$ For Qutb's contempt for "mere abstract knowledge that traffics with minds," "mental logic," "locking up truth inside explanations," and so forth, see his Khașa $\bar{a}^{\supset} i s$, 8, 16, 19-20.

${ }^{55}$ Hanafì, Min al- ${ }^{C}$ Aqìda ilä al-Thawra, vol. III: al- ${ }^{c}$ Adl (Cairo: Maktaba Madbūlī, 1988), 438. Compare this citation to the following one from Qutb:

What is the foundation to which human life reverts and upon which it rests? Is it Allah's religion and its system of life or is it human reality of whatever sort? Islam decisively and unhesitatingly answers this question. The foundation to which the sum and essence of human life must revert is Allah's religion and its system of life.

See $M a^{c} \bar{a}$ lim fi al-Tariq, 92 . Qutb then immediately poses the following interrogatory: "Islam poses the question: are you more knowledgable, or is Allah?" Qutb says that Islam replies: "Allah knows, and you do not know. You have been given only a little knowledge." And he goes on:

He who teaches, creates, and nourishes is the One Who rules. His religion must be the system of life, it is the foundation to which life reverts. As for human reality, theories, and religions, they are corrupt and deviations, resting on the knowledge of human beings, who do not know and to whom only a little knowledge has been given. Allah's religion is not obscure, nor is His system of life vague. It is determined by reference to the second part of the credo: "And Muhammad is His Prophet." It is contingent upon what the Prophet preached about the fundamental texts. If a text exists [about a matter], then the text rules. There can be no ijtihād when it comes to a text. The role of ijtihād comes into play when there is no text, according to the principles established in Allah's system itself, not according to caprices or wishes. "If you dispute in a matter, refer it to Allah and His Prophet" (4:59). The principles established for ijtihād and istinbāt [deductive discovery] are also known and not obscure or vague. No one can say about a law [shar $]$ that has been enacted: "This is Allah's law," unless he has proclaimed 
that sovereignty is Allah's, not the people's, nor a party's, nor any human being's; and unless he reverts to the Qur'an and the Sunnah to know what Allah wants. No one who wants to do so can claim authority in the name of God, which is what Europe experienced in the form of theocracy. There is nothing of this in Islam. No one can speak in Allah's name except His Prophet. There are specific texts, and they are what determine what Allah has legislated. The statement that religion is for the sake of reality is misunderstood and misapplied. Yes, this religion is for the sake of reality, but which reality? The reality that this religion itself establishes, according to its system, which simultaneously is in consonance with human nature, and meeting true human needs in their entirety. These are needs which the Creator has established, and He knows what He has created. . . Religion does not face reality-of whatever kind - in order that it be established and studied by reference to one of its documents and by reference to a legal ruling that relates to it, like a tabula rasa. It faces reality in order to weigh it on its scales, and it establishes what it establishes and discards what it discards. It creates another reality if it is not satisfied with it. The reality that it creates is reality. This is the meaning of the phrase, "Islam is a religion for reality," or what it should mean in its true sense. Perhaps the question may be asked: "Is it not the interest of human beings that forms their reality?" Again, we go back to the question that Islam poses and answers: "Are you more knowledgeable, or is Allah?" "Allah knows, and you do not know." The interest of human beings is contained in Allah's law, as revealed by Allah and propagated by the Prophet [ibid., 93-95].

Repeatedly, Qutb reifies Islam. Even when he speaks about ijtihād and istinbāt, he seems to be imputing historicity to human behavior in a passing and glancing way. "This religion does" or "Islam says" are the operative kinds of expressions in his discourse.

${ }^{56}$ Hanafî, Min al- ${ }^{-}$Aqida ilā al-Thawra, vol. I: Al-Muqaddimāt al-Naz̧ariyya (Cairo: Maktaba Madbūlī, 1988), 39.

${ }^{57}$ See ibid., back cover.

${ }^{58}$ Boullata is wholly persuasive when he says that for Hanafi the turāth consists of "specific realizations of certain beliefs and attitudes under particular historical circumstances"; Issa J. Boullata, Trends and Issues in Contemporary Arab Thought (Albany: State University of New York Press, 1990), 40.

${ }^{59}$ Hanafī, Min al- ${ }^{\complement}$ Aqìda ilā al-Thawra, vol. V: al-İmān wa al- ${ }^{C}$ Amal-al-Imāma (Cairo: Maktaba Madbūlī, 1988), 5.

${ }^{60}$ Abū Zayd, Naqd al-Khițāb al-Dìni, 155.

${ }^{61}$ Hanafi, Min al- ${ }^{c}$ Aqìda ilā al-Thawra, vol. I, 243. On the preceding page, he maintains that:

In modern reformist movements [presumably the Salafiyya] attempts to reconstruct the theory of knowledge or to formulate the theoretical introduction to the science of ușül al-din have not taken place as they did in the past. Instead, the theory of knowledge remained hidden, its place being taken by the description of the historical development of knowledge in order to know what is authentic and what is extraneous to it. The goal of defining the course of knowledge in history is to know how the transition occurs from unity to diffusion. from community to separatedness. so that we can transcend the current condition of diffusion and segmentation to the original condition of unity and community. As a consequence [of this transcendence] the science of $u s \underline{u} l$ al-din will revert to being a guide for the conduct of the people toward action.

\footnotetext{
${ }^{62}$ It has been suggested that Qutb emphasized the importance of theory as the indispensable prerequisite of practice. This is reflected in his use of the word "conception" [tasawwur]. While it is true that Qutb was interested in theory, it is in a way that is different from Hanafi. Hanafi's theory is a critical theory, according to which subject matter is held to be problematical until demonstrated to the contrary. Qutb's theory is essentially an uncritical "Islamic conception" that becomes the template for human action. Action is Qutb's watchword, though the agent that acts is "Islam."

${ }^{63}$ Hanafì, Min al- ${ }^{C}$ Aqidah ilä al-Thawra, vol. I, 89.

${ }^{64}$ Richard Khuri, "A Critique of Hassan Hanafi Concerning His Reflections on the Scarcity of Freedom in the Arab-Muslim World," in Cultural Transitions, 86-115. Khuri explains that in Hanafi's view of history, "residues pile up" over the centuries, with lower levels acquiring great authoritativeness. Control over meaning has been exercised by a self-appointed group that has continued to exercise its power over the long course of history in Islamic societies. In a dialectical relationship, the Ash ${ }^{\complement}$ arite-Ghazalian conceptions exercise their hold over the social group monopolizing power in society, and the social group in turn
} 
strengthens its monopoly of control over the thought by acting as sole gatekeepers to this thought, termed the turāth.

${ }^{65}$ Hanafî, Min al- ${ }^{c}$ Aqìda ilā al-Thawra, vol. I, 35, 75, 211.

${ }^{66}$ Ibid., 5

${ }^{67}$ Ibid., 223.

${ }^{68}$ Hanafi, al-Turāth wa al-Tajdid (Cairo: al-Markaz al- ${ }^{C}$ Arabì li-al-Bahth wa-al-Nashr, 1980), 15.

69"The text does not change in meaning, the interpreter makes it speak in accordance with his wishes. The essential thing is the current reality, for it is what gives the text its purport and its content. Instead of analyzing reality, itself and its constituent elements, there is a reliance on the proof of authority in a society in which the text is a source of authority"; Hanafì, Min al-'Aqida ila al-Thawra, vol. V, 229.

${ }^{70}$ Ibid., I:79.

${ }^{71}$ Ibid., 33 .

${ }^{72}$ Ibid., V:387-88.

${ }^{73}$ Qutb speaks of a "new leadership" (qiyāda jadida) of the "organic dynamic fusion" (tajammuc haraki ${ }^{c} u d w i \bar{l}$ ) - that is, of the vital Muslim masses; Macalim fi al-Tariq, 49.

${ }^{74}$ The use of seemingly modern concepts by scripturalists to vindicate scripturalist ends is stressed in the recent work of Serif Mardin. For example, see his intellectual biography of Said Beddiuzzeman Nursi, Islam and Social Change in Turkey (Albany: State University of New York Press, 1989); also, Mardin, ed., Cultural Transitions in the Middle East. Also, see Sami Zubaida, Islam, the People, and the State, 2nd ed. (London: Routledge, 1994). 